\title{
Gorrespondence
}

\section{Endangered Political Species?}

To the Editors: In his article "Human Rights Are Not a Western Discovery" (Worldview, October) Raúl Manglapus makes reference to my recent book The Decline of Democracy. Attempting to refute one of its general themes, that democratic government is an endangered political species, Mr. Manglapus states that democracy has lately "been making a comeback." Unfortunately his evidence is highly subjective, and the several examples used are only those that he believes support his conclusion.

There are at least an equal number of examples of nations in which democracy has been suspended or terminated within the past two or three years. Among

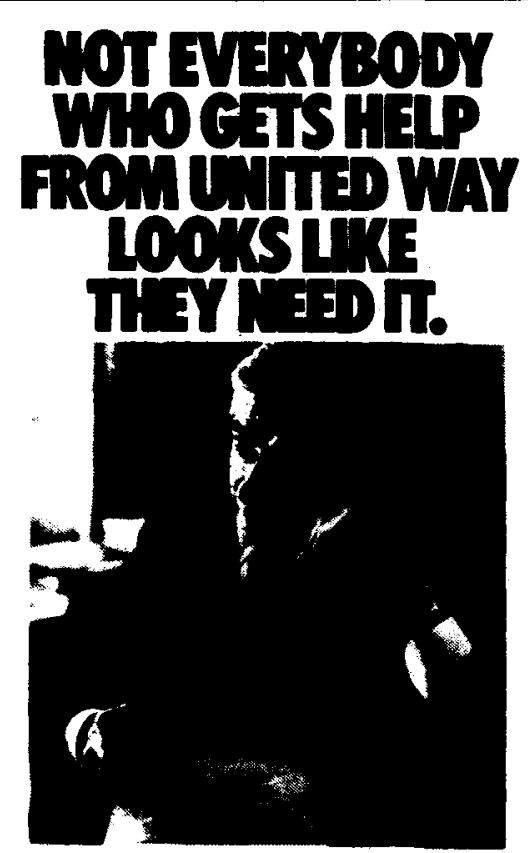

United Way works for all of us. And that means people like you, your family and your friends. Benefiting from services we all tend to take for granted. Like swimming lessons for the kids. Summer camps. Youth organizations. And a lot more



these are Bangladesh, Pakistan, and Argentina. In addition there has been a trend toward curtailment of democratic impulses within several authoritarian states that had shown some liberalizing tendencies at times during the 1970's. These include Kuwait, Nepal, Yugoslavia, Egypt, and several African nations. Mr. Manglapus does not focus on the implications of these situations.

In fact, even the examples given by Mr. Manglapus illustrate the very fragility of democracy and the ease with which it has been subverted in many of the countries he mentions. This is certainly not proof of its enduring presence nor evidence of any deep-seated mass commitment to this form of government. An analysis of political systems around the world, using three minimal criteria of democracy (regular and free elections, with the possibility of changing administrations by the ballot; the existence of an active and legal opposition and its acceptance by the government; the presence of some elements of free expression) indicates that both democratic government and democratic processes are now at a lower level than at almost any time since the end of World War II. The bulk of the world's people and an increasing number of states live in an environment where political authoritarianism has expanded. This makes it difficult to accept $\mathrm{Mr}$. Manglapus's contention that democracy has not declined in our era.

While disagreeing with this and other historically debatable assertions in his article (such as the claim that initial industrial growth can accelerate in a democratic context), I strongly endorse Mr. Manglapus's statements that human rights are not conceptually or operationally exclusive to Western societies. He correctly criticizes Buckley, Hearst, and Kennan for some of their attitudes on this score. They, and Raúl Manglapus, should remember that a thesis is poorly sustained by facts that are squeezed to fit it.

New York, N.Y.
Ralph Buultjens

\section{WORLDVEW \\ Statement of Purpose}

The purpose of Wortdview is to place public policies, particularly in intemational affairs, under close ethical scrutiny. The Council on Religion and International Affairs, which sponsors the joumal, was founded in 1914 by religious and civic leaders brought together by Andrew Camegie. It was mandated to work toward ending the barbarity of war, to encourage intemational cooperation, and to promote justice. The Council is independent and nonsectarian. Worldview is an important pant of the Council's wide-ranging program in pursuit of these goals.

Worldview is open to diverse viewpoints and encourages dialogue and debate on issues of public significance. It is edited in the belief that large political questions cannot be considered adequately apart from ethical and religious reflection. The opinions expressed in Worldview do not necessarily reflect the positions of the Council. Through Wortdview the Council aims to advance the national and international exchange without which our understanding will be dangerously limited.

Philip A. Johnson, Publisher

Editorial Board:

Hans Morgenthau, Chairman

William J. Barnds

Eugene B. Borowitz

Noel J. Brown

Jorge Dominguez

James Finn

J. Bryan Hehir

Donald F. McHenry (on leave)

Paul, Ramsey

Seymour Siegel

Paul Sigmund

Kenneth $W$. Thompson

Howard Wriggins (on leave)

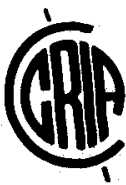

